Int. J. Morphol.,

36(1):109-112, 2018.

\title{
Expression of Endothelin-1 and Ki-67 in Normotensive and Severe Preeclamptic Placentas
}

\author{
Expresión de Endotelina-1 y Ki-67 en Placentas Normotensas y Preeclampsia Severa
}

Aysun Ekinci ${ }^{1}$; Ayfer Aktas²; Ahmet Dönder ${ }^{3}$; Cenap Ekinci²; Abdulkadir Turgut ${ }^{4}$; Senay Deveci ${ }^{3}$ \& Engin Deveci $^{2}$

EKINCI, A.; AKTAS, A.; DÖNDER, A.; EKINCI, C., TURGUT, A.; DEVECI, S. \& DEVECI, E. Expression of endothelin-1 and Ki-67 in normotensive and severe preeclamptic placentas. Int. J. Morphol., 36(1):109-112, 2018.

SUMMARY: Severe preeclampsia (HELLP syndrome) is a life-threatening pregnancy complication, usually a severe form of preeclampsia. In this study, we aimed to examine histopathologic changes and Endothelin-1 and KI-67 expression levels by immunohistochemical methods in severe preeclamptic placentas. Severe preeclampsia and obstetric characteristics and biochemical and hematological characteristics of healthy subjects were compared. Placenta sections were stained with hematoxylin-eosin for histopathological examination. In the histopathological examination of severe preeclamptic placenta, degeneration in synaptic and cytotrophoblastic cells, increase in insidious knots, fibrinoid necrosis, degeneration in endothelial cells, calcification and hyaline villous stains were observed. In the severe preeclampsia group, Ki-67 expression increased in decidua cells and inflammatory cells, while endothelial cells in the vessel wall and inflammatory cells in the villus and intervillous spaces increased. It is thought that angiogenetic and cellular proliferation is induced in a co-ordinated manner and significantly influences fetal development.

KEY WORDS: Hellp syndrome; Placenta; Ki-67 antibody; Endothelin-1.

\section{INTRODUCTION}

HELLP syndrome refers to a syndrome characterized by microangiopathic hemolysis, elevated liver enzymes, and a low platelet count (Sibai et al., 1986). Preeclampsia is associated with the impaired migration/invasiveness of trophoblasts, which leads to endothelial dysfunction, incomplete uterine vascular remodeling, and, consequently, poor perfusion. In a normal pregnancy, the invasion of cytotrophoblasts results in remodeling of the uterine spiral arteries, which is required for placental perfusion. In Preeclampsia, remodeling of the spiral arteries is impaired as a result of poor trophoblast migration/invasion (Chaiworapongsa et al., 2014; Walentin et al., 2016).

Endothelin-1 is a vascular regulator that is produced by endothelial cells and cardiomyocytes, which has vasoconstrictive and mitotic effects via the stimulation of growth factors. It is also important in hypertension, acting as a blood pressure elevator (Schiffrin et al., 1997; Rich \& McLaughlin, 2003). Ki-67, which is seen in the nucleus of proliferating cells, is a marker for proliferation. Ki-67 shows a good correlation with the number of mitotic cells. It is also known as the antigen identified by monoclonal antibody and is usually used for mitotic index and tumor grading (Scholzen \& Gerdes, 2000). The aim of this study is to investigate biochemical histopathological and immunohistochemical effects of placenta in pregnancies complicated with preeclampsia or HELLP syndrome.

\section{MATERIAL AND METHOD}

The study protocol was approved by the Medical Committee of Diyarbakir Hospital Maternity and Child Health Hospital and informed consent was obtained from all subjects involved in the study. The study included 10 pregnant patients with HELLP syndrome (study group) and 10 healthy pregnants at between 34 and 38 weeks gestational age (control group). All placenta tissues were provided from the Diyarbakir Maternity and Child Health Hospital (Department of Obstetrics and Gynecology). Preeclamptic $(n=10)$ and normal placentas $(n=10)$ were received. New

\footnotetext{
${ }^{1}$ Department of Biochemistry, Faculty of Medicine, University of Dicle, Diyarbakır, Turkey.

${ }^{2}$ Ataturk Health High School, Dicle University, Diyarbakır, Turkey.

${ }^{3}$ Department of Histology and Embryology, Faculty of Medicine, University of Dicle, Diyarbakır, Turkey.

${ }^{4}$ Department of Gynecology and Obstetric, Faculty of Medicine, University of Medeniyet, Turkey.
} 
onset hypertension (systolic blood pressure $140 \mathrm{mmHg}$ and/ or diastolic blood pressure $90 \mathrm{mmHg}$ ) and proteinuria (>300 $\mathrm{mg}$ in $24 \mathrm{~h}$ ) were observed in all the patients included in the preeclampsia group. Preeclampsia syndrome was defined when three of the following criteria were positive in the absence of other pathologic conditions: lactate dehydrogenase $(\mathrm{LDH})>600 \mathrm{U} / \mathrm{L}$, aspartate aminotransferase (AST) $70 \mathrm{U} / \mathrm{L}$ or alanine aminotransferase (ALT) $70 \mathrm{U} / \mathrm{L}$, platelet count $<100,000$ cells $/ \mathrm{mm}$. Immediately after delivery, the placental tissue was transported from the delivery room to the laboratory. After preliminary gross examination, tissue samples were obtained from the fetal side of the placenta.The specimens were immersed in $10 \%$ buffered formaldehyde, and $5 \mu \mathrm{m}$ thick sections were cut and made into slides. These were processed for Hematoxylin-Eosin.

Immunohistochemical technique. The placenta samples were fixed with neutral buffered $10 \%$ formalin solution and dehydrated in a graded series of ethanol, Then the tissues were taken 3 times for 5 minutes in PBS solution. Antigen retrieval process was performed in citrate buffer solution ( $\mathrm{pH}$ 6.0) two times: first $7 \mathrm{~min}$, and later $5 \mathrm{~min}$ boiled in a microwave oven at $700 \mathrm{~W}$. The slides were allowed to cool to room temperature for $30 \mathrm{~min}$ and washed in distilled water for 5 min two times. Endogenous peroxidase activity was blocked in $0.1 \%$ hydrogen

Table I. Obstetric characteristics of the Hellp syndrome and control group*.

\begin{tabular}{lcc}
\hline Characteristics & Hellp group & Control group \\
\hline Maternal age (years) & $28.4 \pm 5.7$ & $29.4 \pm 3.8$ \\
Number of living children & $1.5 \pm 2.24$ & $2.25 \pm 1.62$ \\
Gestational age (week) & $32.4 \pm 3.35$ & $33.7 \pm 4.2$ \\
Systolic blood pressure (mmHg) & $160.3 \pm 18$ & $118.3 \pm 6.4$ \\
Diastolic blood pressure (mmHg) & $104.5 \pm 14$ & $72.6 \pm 5.9$ \\
\hline
\end{tabular}

*Data is presented as mean \pm standard deviation.

Table II. Hematological and biochemical parameters of both groups*

\begin{tabular}{lcc}
\hline Blood parameters & Hellp group & Control group \\
\hline HGB & $10.3 \pm 1.6$ & $11.8 \pm 1.18$ \\
WBC & $15146 \pm 4176$ & $10810 \pm 2892$ \\
PLT & $93.2 \pm 48.8$ & $252 \pm 64.4$ \\
ALT & $232 \pm 186$ & $17 \pm 7$ \\
AST & $206 \pm 123$ & $23 \pm 9$ \\
LDH & $901 \pm 353$ & $283 \pm 119$ \\
\hline
\end{tabular}

*Data is presented as mean \pm standard deviation, HGB: Hemoglobin (gram/deciliter), WBC: White blood cell (cells/microliter), PLT: Platelet (cells/microliter), AST: Aspartate aminotransferaseU/L, ALT: Alanine aminotransferase U/L, LDH: Lactate dehydrogenase (international unit/ liter). peroxide for 15 min. Ultra V block (Cat. No: 85-9043, Invitrogen, Carlsbad, CA, USA) was applied for $10 \mathrm{~min}$ prior to the application of primary antibodies (Abcam pSTAT3 antibody 1:150), (AbcamTNF-a antibody 1:100) overnight. Secondary antibody (Cat. No: 85-9043, Invitrogen, Carlsbad, CA, USA) was applied for $20 \mathrm{~min}$. Slides were then exposed to streptavidin-peroxidase for 20 min. Detection was based on the labeled streptavidinbiotin complex technique (LSAB kit, DAKO, Glostrup, Denmark), using 3,3'- diaminobenzidine (DAB) as chromogenic substrate. Control slides were prepared as mentioned above but omitting the primary antibodies. After counterstaining with Hematoxylin, washing in tap water for $5 \mathrm{~min}$ and in distilled water twice for $5 \mathrm{~min}$, the slides were mounted.

\section{RESULTS AND DISCUSSION}

Patients with severe preeclampsia were compared with healthy subjects. Obstetric characteristics, hematological and biochemical parameters were shown. Systolic and diastolic blood pressures, liver function tests and LDH were significantly increased in severe preeclampsia patients, while platelet counts were significantly lower in PE patients than in healthy controls

(Tables I and II).

In the histopathological examination of the normotensive placenta, the decidual cells are ovoid chromatin in the nucleus, and the trophoblastic cells in the chorionic villi are observed as two layers in the middle connective tissues and capillaries. Hypertrophic proliferation, fibrinoid necrosis, endothelial proliferation, calcification and hyaline villous stains were observed in the severe preeclamptic placenta, decidual cells, and degeneration cytotrophoblastic cells (Figs.1a,b,c). In the Hellp placenta group, the expression of Ki-67 was observed in villus cytotrophoblastic cells and decidua cells, but not in synyctiotrophoblast cells. An increase in endothelin-1 expression was observed in endothelial cells and inflammatory cells in the severe preeclampsia group (Fig. 1g).

Placental pre-eclampsia is characterized by an hypoxic placenta subjected to oxidative stress, while maternal pre-eclampsia arises from the interaction between a normal placenta and a maternal system susceptible or suffering 

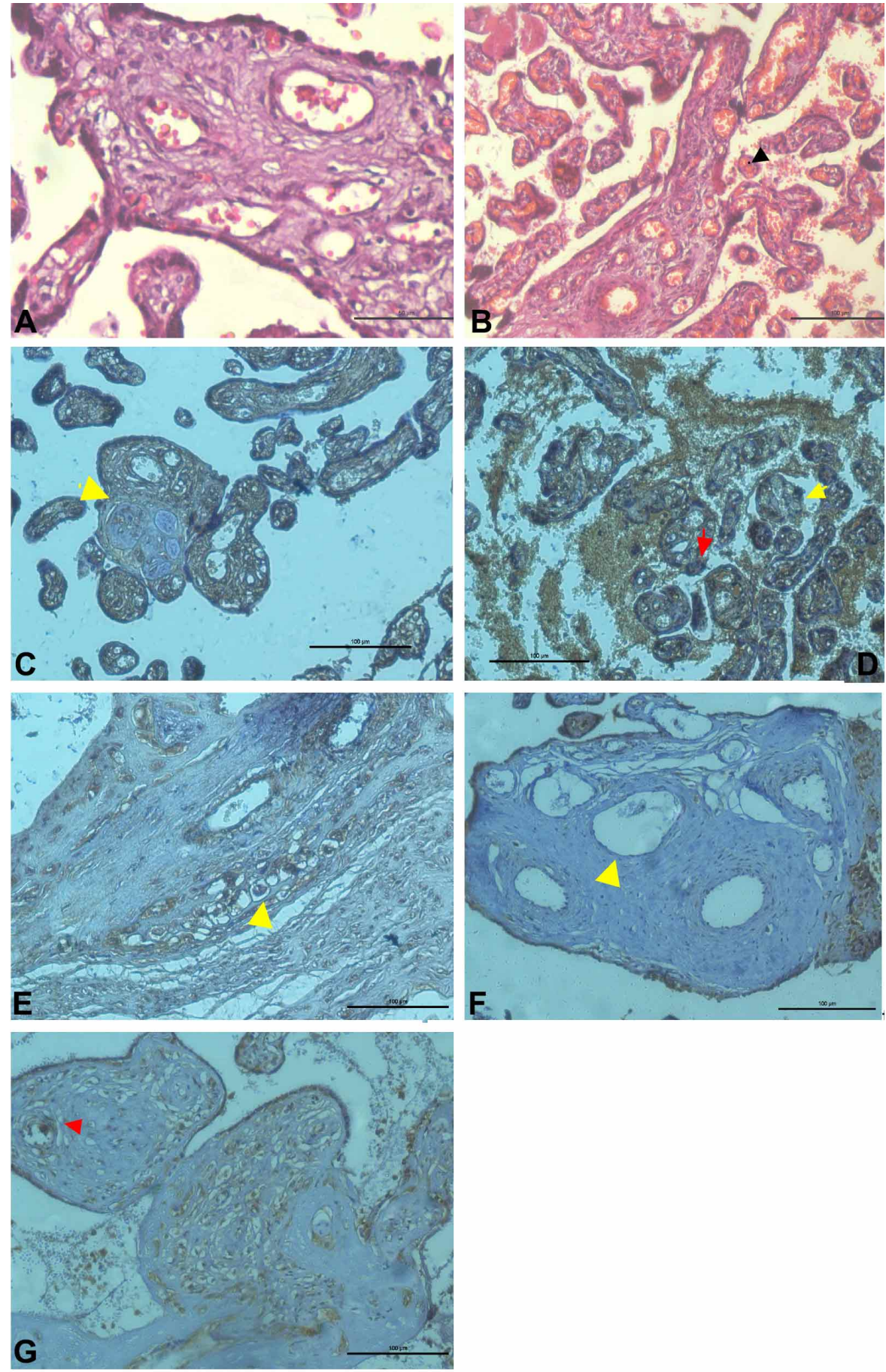

Fig. 1. A. Control group: Normal appearance of trophoblast cells, blood vessels and connective tissue in chorionic villi, H-E Bar $100 \mu \mathrm{m}$. B. Severe preeclampsia group: Dilatation and hemorrhage in capillary vessels Fibrinoid necrosis and an increase fibrous tissue (arrow), H-E Bar $100 \mu \mathrm{m}$. C. Control group: Weak Ki-67 expression in trophoblast cells (arrow), Ki-67 immun-staining Bar $100 \mu \mathrm{m}$. D. Severe preeclampsia Positive expression of Ki-67 in Cytotrophoblast cells (red arrow) and syncytial knots (yellow arrow), Ki-67 immun-staining Bar 100 $\mu \mathrm{m}$. E. Positive expression of

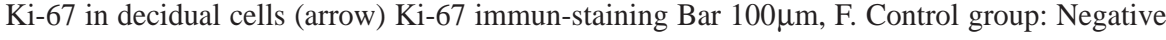
Endothelin -1 expression in endothelial cells (arrow) Endothelin -1 immun-staining Bar $100 \mu \mathrm{m}$, G. Severe preeclampsia: Positive Endothelin -1 expression in endothelial cells and inflamatuar

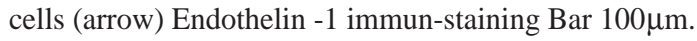

from microvascular diseases, as well as long-term hypertension and/or diabetes (Redman \& Sargent, 2005). Severe preeclampsia is usually considered to be a life-threatening complication of pregnancy. Chronic hypertension is characterized by an increased vascular resistance and modifications in the mechanical properties of blood vessels (Fitzgerald et al., 2008). Degenerative changes in the form of trophoblastic apoptosis were found in placentas from pregnancies complicated by fetal growth restriction, resulting from hypoxia (Heazell \& Crocker, 2008); Jeschke et al. (2006) that compared preeclampsia with normal placenta. The preeclamptic cytotrophoblastic tissue indicated that the expression intensity of $\mathrm{Ki}$ 67 was significantly different from that of normal placental tissue controls (Jeschke et al.). In our study, increased expression of $\mathrm{Ki}$ 67 in preeclamptic villous cytotrophoblastic cells and decidual cells and increase in $\mathrm{Ki}$ 67 in villous cytotrophoblastic cells of HELLP placenta. Levels of endothelin-1 mRNA in trophoblasts were shown to be higher in PE patients than in healthy subjects, which suggests that endothelin- 1 is associated with inadequate trophoblast invasion in PE (Napolitano et al., 2000). It is thought that $\mathrm{Ki}-67$ protein expression is effective in cell division and cell proliferation, Endothelin-1 expression induces angiogenetic effect and inflammation, and coincidentally increases in both groups of heavy preeclamptic placenta groups significantly influence fetal development. 
EKINCI, A.; AKTAS, A.; DÖNDER, A.; EKINCI, C., TURGUT, A.; DEVECI, S. \& DEVECI, E.Expresión de endotelina-1 y Ki-67 en placentas normotensas y preeclampsia severa. Int. J. Morphol., 36(1):109-112, 2018.

RESUMEN: La preeclampsia severa (síndrome de HELLP) es una complicación del embarazo potencialmente mortal, generalmente una forma grave de preeclampsia. En este estudio, nuestro objetivo fue examinar los cambios histopatológicos y los niveles de expresión de Endotelina-1 y Ki-67 mediante métodos inmunohistoquímicos en placentas preeclámpsicas graves. Se compararon la preeclampsia grave y las características obstétricas, además de las características bioquímicas y hematológicas de pacientes sanas. Las secciones de placenta se tiñeron con hematoxilina-eosina para examen histopatológico. En el examen histopatológico de placenta preeclampsia severa, se observó la degeneración en células sinápticas y citotrofoblásticas, un aumento de nudos insidiosos, necrosis fibrinoide, degeneración en las células endoteliales,calcificación y manchas vellosas hialinas. En el grupo de preeclampsia grave, la expresión de Ki-67 aumentó en células deciduas y células inflamatorias, mientras que las células endoteliales en la pared del vaso, y las células inflamatorias en las vellosidades y los espacios intervellosos aumentaron. Se cree que la proliferación angiogenética y celular se induce de forma coordinada y que influye significativamente en el desarrollo fetal.

PALABRAS CLAVE: Síndrome HELLP; Placenta; Expresión Ki-67; Endotelina-1.

\section{REFERENCES}

Chaiworapongsa, T.; Chaemsaithong, P.; Yeo, L. \& Romero, R. Preeclampsia part 1: current understanding of its pathophysiology. Nat. Rev. Nephrol., 10(8):466-80, 2014.

Fitzgerald, J. S.; Poehlmann, T. G.; Schleussner, E. \& Markert, U. R. Trophoblast invasion: the role of intracellular cytokine signalling via signal transducer and activator of transcription 3 (STAT3). Hum. Reprod. Update, 14(4):335-44, 2008.

Heazell, A. E. \& Crocker, I. P. Live and let die - regulation of villous trophoblast apoptosis in normal and abnormal pregnancies. Placenta, 29(9):772-83, 2008.

Jeschke, U.; Schiessl, B.; Mylonas, I.; Kunze, S.; Kuhn, C.; Schulze, S.; Friese, K. \& Mayr, D. Expression of the proliferation marker $\mathrm{Ki}-67$ and of p53 tumor protein in trophoblastic tissue of preeclamptic, HELLP, and intrauterine growth-restricted pregnancies. Int. J. Gynecol. Pathol., 25(4):354-60, 2006.

Napolitano, M.; Miceli, F.; Calce, A.; Vacca, A.; Gulino, A.; Apa, R. \& Lanzone, A. Expression and relationship between endothelin-1 messenger ribonucleic acid (mRNA) and inducible/endothelial nitric oxide synthase mRNA isoforms from normal and preeclamptic placentas. J. Clin. Endocrinol. Metab., 85(6):231823,2000 .

Redman, C. W. \& Sargent, I. L. Latest advances in understanding preeclampsia. Science, 308(5728):1592-4, 2005

Rich, S. \& McLaughlin, V. V. Endothelin receptor blockers in cardiovascular disease. Circulation, 108(18):2184-90, 2003.

Schiffrin, E. L.; Intengan, H. D.; Thibault, G. \& Touyz, R. M. Clinical significance of endothelin in cardiovascular disease. Curr. Opin. Cardiol., 12(4):354-67, 1997

112
Scholzen, T. \& Gerdes, J. The Ki-67 protein: from the known and the unknown. J. Cell. Physiol., 182(3):311-22, 2000.

Sibai, B. M.; Taslimi, M. M.; el-Nazer, A.; Amon, E.; Mabie, B. C. \& Ryan, G. M. Maternal-perinatal outcome associated with the syndrome of hemolysis, elevated liver enzymes, and low platelets in severe preeclampsia-eclampsia. Am. J. Obstet. Gynecol., 155(3):501-9, 1986

Walentin, K.; Hinze, C. \& Schmidt-Ott, K. M. The basal chorionic trophoblast cell layer: An emerging coordinator of placenta development. Bioessays, 38(3):254-65, 2016.

\author{
Corresponding author: \\ Dr. Engin Deveci \\ Department of Histology and Embryology \\ Dicle University Faculty of Medicine \\ Diyarbakır \\ TURKEY
}

Email: engindeveci64@gmail.com

Received: 13-07-2017

Accepted: 23-10-2017 